\title{
Suomi, ota kiinni jos saat
}

Olli Turunen

\section{NÄLKÄMAASTA}

HYVINVOINTI-

Koponen, Juhani ja Saaritsa, Sakari (toim.) Nälkä-

maasta hyvinvointivaltioksi: Suomi kehityksen kiinni-

ottajana. Gaudeamus, 2019.

\section{VALTIOKSI}
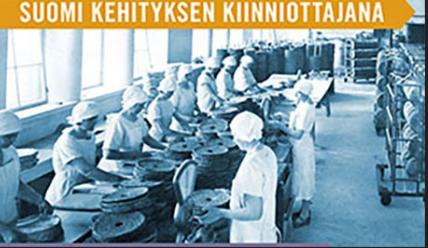

Suurten linjojen talous- ja sosiaalihistorian ystävää on hemmoteltu viime vuosina Suomen mitassa pienoisella kirjatulvalla. Pertti Haapalan toimittama makrorakenteita luotaava Suomen rakennehistoria: Näkökulmia muntokseen ja jatkuvuuteen (1400-2000) (Haapala 2018) ehti ensimmäisenä, ja Jaana Laineen ja kumppaneiden toimittama ja 1960-luvun jälkeistä aikaa käsittelevä Vaurastumisen vuodet: Suomen taloushistoria teollistumisen jälkeen julkaistiin vuoden 2019 keväällä (Laine ym. 2019). Syksyllä 2019 julkaistu Juhani Koposen ja Sakari Saaritsan toimittama Nälkämaasta hyvinvointivaltioksi täydentää sarjaa hienosti, mutta on myös osin päällekkäinen ja limittäinen aiempien teosten kanssa niin teemojen kuin kirjoittajienkin osalta. Lukijaa tämä ei kuitenkaan rasita, koska kirjoittajilla on pitkien tutkijanurien tuomaa näkemystä. Käsillä olevan teoksen kirjoittajissa ja toimittajissa on kymmenkunta emeritusta ja emeritaa historiantutkimuksen eri aloilta. Monet vanhemman polven tutkijoista ovat edelleen erittäin aktiivisia, mutta tilinteosta puhuminen on ehkä liikaa. Jonkinlainen tutkijapolven kokemuksen tiivistymä kirja silti on (yhdessä edellä mainittujen kanssa).

Saaritsan ja Koposen johdantoartikkeli tarjoaa nopean mutta kuitenkin kattavan perehdytyksen talous- ja sosiaalihistorian sekä kehitystutkimuksen kansainvälisiin teorioihin ja kysymyksenasetteluihin, minkä jälkeen se siirtyy käymään läpi suomalaisen tutkimuksen kysymyksenasetteluja ja teoreettisia viitekehyksiä. Saaritsa ja Koponen esittävät, että teos poikkeaa aiemmasta tutkimuksesta (ja myös jo edellä mainituista yleisesityksistä) siinä, että pitkän aikavälin empiirinen tarkastelu yhdistetään teoreettiseen taloudellisesta ja sosiaalisesta kehityksestä käytyyn keskusteluun. Tärkeä on myös huomio siitä, että kehitystutkimuksen ja historiantutkimuksen yhteys on ollut heikko. Saaritsan toinen johdantoartikkeli esittelee tilastojen pohjalta kuinka ja milloin Suomi lakkasi olemasta kehitysmaa ja kuinka kehittyneiden länsimaiden taso saavutettiin. Vertailu edelläkävijöiden ohella perifeerisempiin verrokkimaihin on myös valaisevaa, koska esimerkiksi väestön kouluvuosilla mitattu koulutustaso saavutti perifeerisen ryhmän vasta 1970-80-luvuilla, ja Länsi-Euroopan vasta vuosituhannen vaihteessa. Muita vertailuindikaattoreita ovat luku- ja kirjoitustaito, BKT, HHDI ja elinajanodote. Kiinniotettavaa ja otettua matkaa kuvaa myös hienosti Sakari Heikkisen tarkastelema ajallinen etäisyys edelläkävijöihin. Suomi saavutti Britannian vuoden 1750 tulotason ensimmäisen kerran vuonna 1898, vasta 148 vuoden jälkeen. 2008 ero Yhdysvaltoihin oli 13 vuotta. Sen jälkeen väli onkin taas kasvanut.

Johdanto-osan ohella kirjan artikkelit on jaettu neljään osaan. Osassa Lähtökohdat ja pitkät linjat Ilkka Nummela, Yrjö Kaukiainen, Antti Häkkinen ja Andrew G. Newby luo- 
taavat Ruotsin itäisten maakuntien ja myöhemmin autonomisen suuriruhtinaskunnan tilaa esimodernista teollistumisen kynnykselle. Nummela tarkastelee maatalouden muutosta erätaloudesta teollistumisen alkuun. Maatalouden agraarivallankumousta ennen teollistumista korostava näkemys ohittaa jossain määrin sen uudemman taloushistorian näkemyksen, että ainakin Englannissa maatalouden tuottavuuden kasvu vaikuttaisi olleen kytköksissä urbanisaatioon kysynnän ja myös esimerkiksi saatavilla olleiden lannoitteiden kautta. Maatalouden tuottavuus olisi siis kasvanut käsi kädessä urbanisaation ja teollistumisen kanssa jos ei peräti sen seurauksena. Suomi oli tietysti agraarinen huomattavasti kauemmin, mutta on mahdollista, että hitaaseen maatalouden kaupallistumiseen ja tuottavuuden kasvuun vaikutti meillä suurten keskusten puute. Kaukiaisen artikkelin nostaa hienosti esille sen, että esimodernin ajan köyhyys valtiollisella tai kansallisella tasolla oli enemmänkin sitä, että suuria, urbaaneja kauppaa ja veroista elävää aatelistoa ja siten kerska- ja harkinnanvaraista kulutusta keskittäviä kaupunkeja ei juuri ollut. Muuallakin Euroopassa maaseudun rahvas eli köyhyydessä ja Elben itäpuolella usein vielä maaorjuudessa. Suomessa elintarvikkeiden niukkuus jatkui kuitenkin poikkeuksellisen pitkään, ja Antti Häkkisen ja Andrew G. Newbyn artikkeli käsitteleekin 1860-luvun mittavaa nälkäkriisiä Suomen saaman kansainvälisen hätäavun näkökulmasta, mikä hienosti konkretisoi Suomen silloisen statuksen nälkä- ja kehitysmaana.

Seuraavassa Kehitykesen prosessit -osassa kirjoittajat pureutuvat keskeisiin talous- ja sosiaalihistorian ilmiöihin. Sakari Heikkinen arvioi valtion ja taloudellisen kehityksen suhdetta keskeisten kehitysteorioiden näkökulmasta. Valtiovetoisen big push -mallin sijaan Suomen kehitys varsinkin autonomian aikana sopii paremmin Robert Allenin "standardimalliin" (rautateitä, tulleja, pankit ja rahajärjestelmä, kouluja), joskin tullien osalta yhteys Venäjään loikin poikkeavan tilanteen ja koululaitoksen osalta Suomi oli kertakaikkisen myöhässä. Monessa mielessä Suomi kasvoi vientivetoisena avotaloutena jo ensimmäisen globalisaation kaudella. Matti Peltonen tarkastelee globalisaation ja maatalouden kaupallistumisen vaikutuksia kotitalouksien tulonmuodostukseen ja tulorakenteeseen, ja argumentoi, että talonpoikaisen maatalouden pysähtyneisyyttä korostavat duaalimallit kuvaavat huonosti perheviljelmiä kohti siirtyvää maataloutta ensimmäisen globalisaation kaudella vuosisadan vaihteessa. Lasten työntekoa maalla, kaupungeissa sekä teollisuudessa; naisten työtä ja tasa-arvoa sekä maastamuuttoa käsittelevissä artikkeleissa Marjatta Rahikainen, Pirjo Markkola ja Ann-Catrin Östman sekä Hanna Snellman nostavat miljoonia suomalaisia koskettaneet ilmiöt iholle. Kytkös pitkän linjan teoreettisempaan keskusteluun tuo taas esille sen, että niin lasten työnteko, naisten raskas työ kuin maastamuuttokin on yhteiskunta- ja talouspoliittisessa viitekehyksessä nähty sekä ongelmina että positiivisina ratkaisuna vielä pahempiin ongelmiin.

Osassa Visiot ja ajurit Pauli Kettunen, Risto Alapuro, Laura Ekholm ja Riitta Hjerppe sekä Arto Kokkinen kytkevät ideat ja aatteet kehityskulkuihin Suomessa. Ekholm ja Hjerppe käsittelevät ulkomaisen omistuksen, yrittämisen ja protektionismin problematiikkaa. Kettunen hahmottelee kuinka "perifeerinen avantgardismi" rakensi kansakuntaa pohjoismaisin vaikuttein itäisessä imperiumissa ja kuinka modernius 1930-luvulla tuli osaksi pohjoismaisuuden käsitettä. Alapuro tarkastelee eliittejä kansakunnan rakentajina institutionaalisessa viitekehyksessä ja argumentoi, että autonomisen suomen virkaeliitti oli nuorta ja asemansa ja statuksensa velkaa autonomiselle valtiojärjestykselle (esim. Baltian aateliprivilegioiden sijaan). Tämä osaltaan vaikutti siihen, että Suomeen rakennettiin inklusiivisia talouden instituutioita (Daron Acemoglun ja J.A. Robinsonin hengessä). Tällaisen teknologisen ja sivistyksellisen ulottuvuuden sisältävän hyvän kehän korostamisen näkökulmasta voi kuitenkin huomauttaa, että autonomian ajan poliittinen ja sivistyksellinen eliitti kuitenkin epäonnistui muualla 
modernisaatioprosessiin oleellisesti kuuluneen inklusiivisen kansanopetuksen järjestämisessä puhumattakaan laajemmin inklusiivisesta korkeammasta opetuksesta. Kuten Sakari Heikkinen ja Marjatta Rahikainen tuovat artikkeleissaan esille, universaali koulujärjestelmä ja oppivelvollisuus saatiin aikaan vasta sotien välillä viimeisenä maana Länsi-Euroopassa. Tämä tapahtui 158 vuotta Fredrik Suuren Preussissa säätämän yleisen kouluvelvollisuuden jälkeen, ja näkyy myös Kokkisen laskemassa inhimillisen pääoman varannossa.

Kettusen "perifeerisessä avantgardismissa" ja Alapuron hyvän kehää ja inklusiivisia instituutioita edistävässä eliitissä kiteytyy Suomen autonomian ajan talous- ja poliittisen historian tulkinnan moni ongelma, mikä sitoo kirjan artikkeleissa käsiteltyjä maa-, maatalous-, markkina-, työmarkkina-, koulutus- ja sosiaalireformeja yhteen. Positiivisten kehityskulkujen juuria etsiessä ei lopulta pääse karkuun sitä, että 1860-luvun nälkävuodet olivat hirvittävät, koulutus- ja sosiaalireformit olivat myöhässä ja työväki lähti lopulta aseelliseen kapinaan. Kettunen siteeraa Yrjö-Sakari Yrjö-Koskisen vuoden 1874 pohdintoja myöhästyneen aseman hyväksikäytöstä muiden virheistä oppimisessa, teknologian omaksumisessa ja työväestön tilanteen seuraamisessa, mutta kyettiinkö tähän todella vai ajoiko historia "tilanteen seuraajien” ohi? Ruotsissahan on esitetty, että 1860-luvun Pohjois-Ruotsin nälänhädässä Ruotsi saavutti pohjan, josta paremman maan rakentaminen alkoi (Västerbro 2018). Samoin Venäjän katastrofaalinen epäonnistuminen Volgan vuosien 1891-92 nälänhädän hoidossa radikalisoi väestöä, kun viljan vienti länteen oli tärkeämpää hallinnolle.

Viimeisessä, Vaarat ja mahdollisuudet -osassa toteutuneet, mahdolliset ja vähän mahdottomatkin kehityskulut saavat osansa. Markku Kuisma käy läpi maanomistusolojen kehityksen avainkohtia ja etenkin Lex Pulkkisen hyödyllisyyttä siinä, että se esti metsäomaisuuden kasaantumisen metsäyhtiöille ja siten kytki metsäteollisuuden kasvun tiukasti muuhun yhteiskuntaan. Kuisma on hieman eri linjoilla edellä mainitun Matti Peltosen kanssa siinä, mikä merkitys metsätuloilla oli ennen itsenäisyyden ajan maareformeja. Kuisman mielestä metsätulot olivat oleellinen lisä maataloudessa, vaikka suhteessa väestöön maaomaisuus oli melko keskittynyttä ennen reformeja. Aappo Kähönen kirjoittaa Suomesta nationalismin ja vallankumouksen ristipaineessa, jossa rakenteet veivät kohti skandinaavista kehitystä, mutta tapahtumat uhkasivat viedä kohti kumouksia, sotia ja kommunismia. Matti Hannikainen käy läpi sosiaalivakuutuksen suunnittelua, jossa 1900-luvun alusta lukien tukeuduttiin vertailuun, mittaamisen ja ekonomisointiin. 1930-luvun lama toi uuden impulssin tutkimukseen ja suunnitteluun (sekä kansaneläkelain 1937). Kuitenkin vasta 1960-luvulla sosiaalipolitiikka alkoi irtautua köyhäinhoidosta kohti kasvuhakuista yhteiskuntapolitiikkaa. Niklas JensenEriksen kirjoittaa korruptiosta, suomalaisessa historiantutkimuksessa vähemmällä jääneestä mutta tärkeästä aiheesta. Pienessä maassa korruptio on saanut omat leimalliset muotonsa, ja Jensen-Eriksen esittääkin, että pohjoismaisen yhteiskunnan avainpiirteet avoimuus ja läpinäkyvyys eivät ole ulottuneet vaalirahoitukseen.

Taloushistorian viimeaikaisten keskustelujen näkökulmasta teoksesta puuttuu jossain määrin kulutuksen näkökulma. Onneksi edellä mainitussa Vaurastumisen vuodet -kirjassa sitä huomioitu. Teollistumisen taloushistoriassa kysymys on ajankohtainen, ja yhtenä taustasyynä on ollut vaikeudet löytää merkkejä yritteliäisyyden tai kaupallisuuden vallankumouksesta massojen kulutusmahdollisuuksissa Britanniassa teollistumisen alkuvaiheessa 1790-1850 (Berg 2018). Massojen kulutusmahdollisuuksien vertailu auttaa myös arvioimaan perässätulijoiden kiinnikuromisen tahtia. Koulutuksen, tekniikan ja teknologian historian kannalta koulutuksen ja tieteen osuus ja kytkökset talouteen käsitellään kyllä ansiokkaasti mutta myös hieman abstraktilla, koulutuksen roolia kasvuteorioissa käsittelevällä tasolla Arto Kokkisen 
artikkelissa. Kirjassa nostetaan hienosti esiin se, kuinka myöhässä ja alkuun puutteellisia koulutusuudistukset Suomessa olivat. Esimerkiksi vielä 1930-luvulla kolmannes maaseudun kansakoululaisista kävi lyhennetyn oppimäärän supistettua koulua. Perusopetuksen, oppikoulujen ja korkeamman koulutuksen jälkeenjääneisyys on kuitenkin taloushistorian kannalta niin oleellinen kysymys, että se ansaitsisi laajemman, ehkä jopa kontrafaktuaalisen tarkastelun.

Kirja on terveellistä luettavaa kaikille, joille vaikkapa Suomen elintaso, koulutusjärjestelmä ja terveydenhuolto ovat alkaneet tuntua itsestäänselvyyksiltä. Ajatus Suomesta pitkän linjan inhimillisenä kehittäjänä ei oikein kestä tarkastelua. Monet keskeisiä järjestelmiä koskevat päätökset tehtiin myöhään, lopulta paineen alla lyhyen ajan sisällä, ja historiallisessa katsannossa niiden vaikutukset olivat nopeita. Tämä on myös tutkimuksen kannalta oleellista siinä mielessä, että institutionaalisesta näkökulmasta taloushistoriassa on usein etsitty pitkän ajan evolutiivisesti kehittyviä selittäviä tekijöitä. Suomen tapaisen maan vertailu aiemmin teollistuneisiin maihin korostaa kuitenkin joidenkin keskeisten päätösten suurta merkitystä. Kiinniotto oli nopeaa, kun rakenteet saatiin kuntoon. Tämä ei kuitenkaan ole universaali tarina, joten institutionaaliset, pitkän linjan selitysmallit nousevat silti selittämään sitä, että tärkeät päätökset oleellisista rakenteista voitiin tehdä. Nopeasti digitoituvassa jälkiteollisessa palveluyhteiskunnassa, jossa finanssisektorilla on vielä korostunut asema, selkeitä esikuvia on kuitenkin vähemmän tarjolla.

\section{Kirjallisuus}

Berg, Maxine. 2018. "Consumption and Global History in the Early Modern Period". Teoksessa Global Economic History, toimittanut Giorgio Riello ja Tirthankar Roy, 1 edition. Bloomsbury Academic.

Haapala, Pertti, toim. 2018. Suomen rakennehistoria: Näkökulmia muutokseen ja jatkuvuuteen (1400-2000), Tampere: Vastapaino.

Laine, Jaana, Susanna Fellman, Matti Hannikainen, ja Jari Ojala, toim. 2019. Vaurastumisen vuodet: Suomen taloushistoria teollistumisen jälkeen. Gaudeamus.

Västerbro, Magnus, kirjoittaja. 2018. Svälten: hungeråren som formade Sverige. Stockholm: Albert Bonniers förlag. 